\title{
Ingoldian fungi from semiarid Caatinga biome of Brazil. The genus Campylospora
}

\section{Fiuza PO $^{1 *}$ and Gusmão LFP}

\author{
${ }^{1}$ Universidade Estadual de Feira de Santana, Departamento de Ciências Biológicas, Laboratório de Micologia, Av. \\ Transnordestina, s/n, Novo Horizonte, 44036-900, Feira de Santana, BA, Brazil. patyfiuzabio@gmail.com
}

Fiuza PO, Gusmão LFP 2013 - Ingoldian fungi from semiarid Caatinga biome of Brazil. The genus Campylospora. Mycosphere 4(3), 559-565, Doi 10.5943/mycosphere/4/3/9

\begin{abstract}
All three species of the genus Campylospora (C. chaetocladia, C. filicladia and C. parvula) were found in foam samples collected in water bodies of three areas in the semiarid region, northeast Brazil. Campylospora filicladia is a new record for Brazil. Descriptions, comments, geographical distribution, illustrations and a key to the genus is provided.
\end{abstract}

Key words - anamorphic fungi - hyphomycetes - lotic environment - taxonomy - tropical

\section{Introduction}

Campylospora Ranzoni was established in 1953. The type species, C. chaetocladia Ranzoni, is characterized by simple, small, conidiophores with monoblastic conidiogenous cells, and staurosporous asymmetric conidia, consisting of a basal cell (deltoid) and a lateral cell (allantoid), both with two diverging branches at each end (Ranzoni 1953, Nawawi 1974). Campylospora chaetocladia has been found in water bodies in many parts of the world including Africa (Ingold 1956, 1958, Dixon 1959), Central America (Santos-Flores \& Betancourt-López 1997), North America (Crane 1968), South America (Cressa \& Smits 2007), Asia (Nemade et al. 2010), Europe (Nilsson 1964) and Oceania (Regelsberger \& Messner 1987).

The second species, C. parvula Kuzuha was described on submerged leaves in Tokyo, Japan (Kuzuha 1973). This species has the smallest branches of the genus. According to Kuzuha (1973), the material reported by Ingold \& Ellis (1952) is similar to C. parvula. Campylospora filicladia Nawawi, proposed in 1974, has the thinnest branches in the genus (Nawawi 1974).

Conidia of Campylospora have been reported in many parts of the world (Chauvet 1991, Santos-Flores \& Betancourt-López 1997). The genus is usually found in water (Fabre 1998), submerged leaves (Ranzoni 1953, Nawawi 1974, Kane et al. 2002) and foam (Santos-Flores \& Betancourt-López 1997). Campylospora parvula was reported as endophytic in roots of Lyonia ovalifolia (Sati \& Belwal 2005) and Alnus glutinosa (Fisher \& Petrini 1989), while C. chaetocladia was found as an endophyte in Murraya koenigii (Sati \& Belwal 2005).

Although the genus is frequently found, full characterization and description of new species is reserved only for the species isolated in pure culture. Some similar conidia of Campylospora were collected by Ingold \& Ellis (1952) and Ingold (1959), however, these authors only indicate the possibility of new species, since the fungi were not isolated in pure culture. Thus, the diversity of Ingoldian fungi, and particularly Campylospora, may be underestimated. 


\section{Methods}

The material described in this study was derived from foam samples collected in water bodies of three areas in the semiarid Caatinga biome in the northeast of Brazil. These areas are considered of high biological importance (Velloso et al. 2002), and are located at Chapada do Araripe and Serra de Ibiapaba from Ceará state and Brejo Paraibano from Paraíba state. For observation of Ingoldian fungi, the technique proposed by Descals (2005) was applied. The foam samples were collected and packaged in plastic bottles of $250 \mathrm{~mL}$ and adding $5-10 \mathrm{~mL}$ of alcohol (70\%). The material collected was homogenized and $0.2 \mathrm{~mL}$ of each sample was transferred to slides. The slides were exposed at room temperature to complete evaporation. A drop of lactic acid was added to the slides and then a cover slip which was sealed with nail polish. The identification was made from the observation of micro morphological characters of conidia and compared with specific literature. The illustrations were made by camera lucida coupled to an Olympus BX-51 microscope. The materials were deposited in the Herbarium of the State University of Feira de Santana (HUEFS).

\section{Results}

All of the three described Campylospora spp., C. chaetocladia, C. filicladia and C. parvula, were found in Brazil along with a fourth species that is not determined to species.

Campylospora Ranzoni, Farlowia 4: 373, 1953.

Conidia tetraradiate, hyaline, composed of two parts, deltoid and allantoid; both with two diverging branches at the ends; schyzolitic secession.

Campylospora chaetocladia Ranzoni, Farlowia 4: 373, 1953.

Figs 1-2

Conidia tetraradiate, hyaline, composed of two parts, deltoid and allantoid; both with two diverging branches at the ends; deltoid with 3-4 cells, $6-9 \times 12-15 \mu \mathrm{m}$; allantoid with 3-4 cells, $10.5-16.5 \times 3-6 \mu \mathrm{m}$; basal cells truncated; apical cells of both parts are triangular to pyramidal; branches with tapered apex, 0-septate, 30-50 × 1.5-3 $\mu \mathrm{m}$.

Material examined - BRAZIL. Ceará: Missão Velha, Chapada do Araripe, River Missão Velha, in foam, 2 Aug 2011, P.O. Fiuza (HUEFS 141553); BRAZIL. Paraíba: Alagoa Grande, Brejo Paraibano, River Pitombeira, in foam, 16 Dec 2011, P.O. Fiuza (HUEFS 141557); BRAZIL. Ceará: Ubajara, Serra de Ibiapaba, Stream Gameleira, in foam, 15 Jun 2012, P.O. Fiuza (HUEFS 141558).

Geographical distribution - Cosmopolitan.

Campylospora chaetocladia differs from other species by having larger branches $(35-50 \times$ 3-5 $\mu \mathrm{m}$ ) and the apical cells of conidia are triangular to pyramidal (Ranzoni 1953). The characteristics and dimensions of the collected material are in agreement with those mentioned by Ranzoni (1953), except for the branches, which are narrower. The conidia found in Brejo Paraibano, had crossed apical branches (Fig. 1), which usually occurs in C. filicladia. Ingold \& Cox (1957) studying C. chaetocladia and Tripospermum myrti (Lind) S. Hughes in pure culture, noted that the two genera have a similar development of conidia. These authors considered the possibility of transferring Campylospora to Tripospermum. Campylospora chaetocladia has been found on every continent. It is frequently recorded in subtropical to tropical waters, which is corroborated by Chauvet (1991), who recorded the species prefers waters with a temperature $\geq 16^{\circ} \mathrm{C}$. In South America, C. chaetocladia was recorded in Venezuela by Cressa \& Smits (2007) and Brazil in São Paulo by Schoenlein-Crusius \& Milanez (1990) and Schoenlein-Crusius (2002), and Minas Gerais by Rosa et al. (2009). This is the first record in Brazilian semiarid.

Campylospora filicladia Nawawi, Trans. Br. mycol. Soc. 63(3): 604, 1974.

Fig. 3

Conidia tetraradiate, hyaline, composed of two parts, deltoid and allantoid; both with 4 cells and two diverging hair like branches at the ends; deltoid, 6-9 × 10.5-13.5 $\mu \mathrm{m}$; allantoid 10.5-13.5 
$\times 4.5-6 \mu \mathrm{m}$; basal cells truncated; apical cells of both parts rounded; branches with tapered apex, 0 septate, $16.5-25.5 \times 0.5-0.7 \mu \mathrm{m}$; apical branches crossed.

Material examined - BRAZIL. Ceará: Ubajara, Serra de Ibiapaba, River Minas, in foam, 18 Jul 2012, P.O. Fiuza (HUEFS 141559).

Geographical distribution - Australia (Matsushima 1989); China (Chan et al. 2000); India (Sridhar \& Kaveriappa 1992, Ravijara et al. 1998); France (Fabre 1998); Malaysia (Nawawi 1974); Puerto Rico (Santos-Flores \& Betancourt-López 1994, 1997); New Zealand (Aimer \& Segedin 1985); Taiwan (Matsushima 1980); Venezuela (Castañeda-Ruiz et al. 2003, Silva \& Briedis 2009, 2011).

Campylospora filicladia is characterized by the rounded apex of apical cell and the thinnest branches in the genus (Nawawi 1974). The characteristics and dimensions are in accordance with Nawawi (1974), except for the wide of the branches $(0.5-0.7 \mu \mathrm{m})$. Campylospora filicladia is generally observed with the apical branches crossed (Nawawi 1974, Santos-Flores \& BetancourtLópez 1997). Santos-Flores \& Betancourt-López (1997) provided an identification key for the genus, using the crossing branches as an important step, however, after observation of various materials, we believe it is not a diagnostic feature for the species. Campylospora filicladia was recorded on decaying leaves of Canna generalis and litter by Matsushima (1980, 1989). This is the first record for Brazil.

Campylospora parvula Kuzuha, J. Jap. Bot. 48 (7): 220, 1973.

Fig. 4

Conidia tetraradiate, hyaline, composed of two parts, deltoid and allantoid; both with 4 cells and two diverging setose branches at the ends; deltoid, $8-12 \times 13.5-15 \mu \mathrm{m}$; allantoid $12-13.5 \times 4.5-$ $6 \mu \mathrm{m}$; basal cells truncated; apical cells of both parts pyramidal; branches 0 -septate, $4.5-6 \times 1.5 \mu \mathrm{m}$.

Material examined - BRAZIL. Ceará: Ubajara, Serra de Ibiapaba, Stream Gameleira, in foam, 27 Jul 2012, P.O. Fiuza (HUEFS 141558).

Geographical distribution - Africa (Chen et al. 2000); Austria (Voglmayr 1996); Brazil (Schoenlein-Crusius \& Grandi 2003); Canada (Barlocher 1987); England (Ingold 1974, 1975, Fisher \& Petrini 1989); France (Wood-Eggenschwiler \& Barlocher 1983); Germany (WoodEggenschwiler \& Barlocher 1983); India (Sridhar \& Kaveriappa 1992, Ravijara et al.1998, Sati \& Belwal 2005, Sati \& Arya 2009); Ireland (Harrington 1997); Japan (Kuzuha 1973); Peru (Matsushima 1993); Puerto Rico (Betancourt et al. 1987, Santos-Flores \& Betancourt-López 1994, 1997); Sweden (Nilsson 1964); Switzerland (Wood-Eggenschwiler \& Barlocher 1983); Taiwan (Matsushima 1980); Venezuela (Silva \& Briedis 2009, 2011).

Campylopora parvula has the smallest branches of the genus. The characteristics and dimensions agree with the literature (Kuzuha 1973), although the branches are smaller. According to Nawawi (1974), the finger-shaped branch on the conidia was not mentioned in the description or shown in the drawing of Kuzuha (1973). Ingold (1974) observed conidia in foam very similar to those found by Kuzuha (1973) and pointed out that the author of the species would not have observed the finger-shaped branch and registered it as an appendix. Campylospora parvula was found by Matsushima (1980) in leaves of Canna generalis. Later, Fisher \& Petrini (1989) observed the species as endophytic in roots of Alnus glutinosa. Campylospora parvula was observed in Brazil, São Paulo (Schoenlein-Crusius \& Grandi 2003). This is the first record from Brazilian semiarid.

\section{Campylospora sp.}

Fig. 5

Conidia tetraradiate, hyaline, composed of two parts, deltoid and allantoid, both with two diverging branches at the ends; deltoid triangular to pyramidal with 4 cells, $7.5-9 \times 13.5-15 \mu \mathrm{m}$; allantoid with 3 cells, $12-13.5 \times 3-4.5 \mu \mathrm{m}$; basal cells with ends rounded; apical cells of both parts rounded; branches 0 -septate, $18-20 \times 1-2 \mu \mathrm{m}$.

Material examined - BRAZIL. Ceará: Ubajara, Serra de Ibiapaba, River Minas, in foam, 28 May 2012, P.O. Fiuza (HUEFS 141559). 
The conidia of this species are similar to those of $C$. filicladia in dimensions of allantoids, deltoid and apical cells rounded. However, these conidia have branches that are wider than those of C. filicladia, being, for this feature, closer to C. chaetocladia. This taxon differs from other species of Campylospora in having basal cells with a rounded base. Unfortunately, these conidia were not isolated and grown in pure culture, and thus it is impossible to clarify it as a new species.

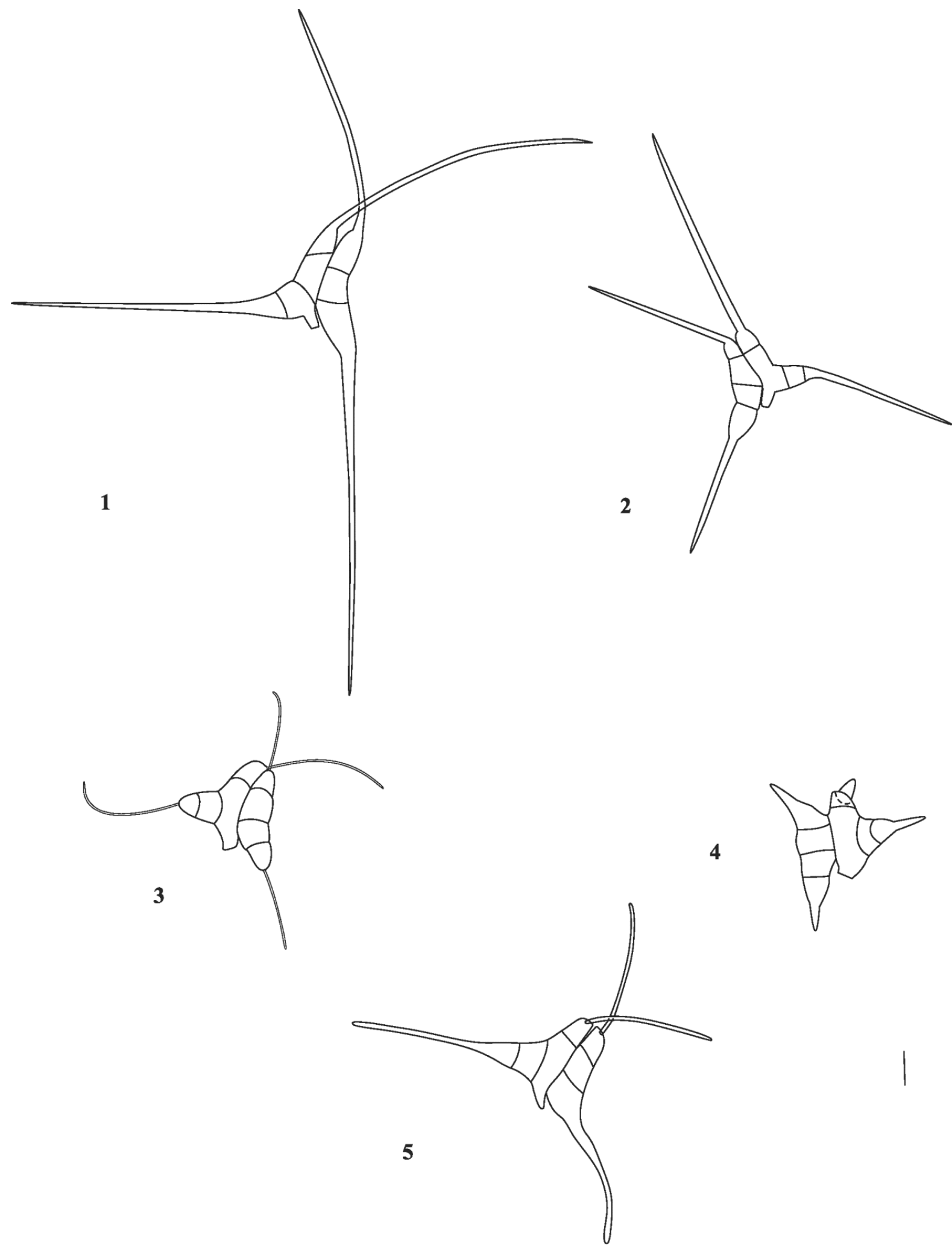

Figs 1-5 - Conidia of Campylospora spp. 1, 2 C. chaetocladia. 3 C. filicladia. 4 C. parvula. 5 Campylospora sp. - Bar $=5 \mu \mathrm{m}$. 


\section{Key to species of Campylospora}

1a. Conidia basal cells truncated

1b. Conidia basal cells rounded

Campylospora sp.

2a. Conidia branches less than $15 \mu \mathrm{m}$ long. C. parvula

2b. Conidia branches more than $15 \mu \mathrm{m}$ long 3

3a. Conidia branches less than $1 \mu \mathrm{m}$ wide.

3b. Conidia branches more than $1 \mu \mathrm{m}$ wide

C. chaetocladia

\section{Acknowledgements}

The authors PO Fiuza and LFP Gusmão wish to thank to "Programa de Pesquisa em Biodiversidade do Semiárido" for financial support in collecting. PO Fiuza wish to thank to "Programa de Pós-graduação em Botânica (UEFS)" and "Coordenação de Aperfeiçoamento de Pessoal de Nível Superior (CAPES)" for granting scholarships and LFP Gusmão extended thanks to $\mathrm{CNPq}$ (proc. 303924/2008-0).

\section{References}

Aimer RD, Segedin BP. 1985 - Some aquatic hyphomycetes from New Zealand streams. New Zealand Journal of Botany 23, 273-299.

Barlocher F. 1987 - Aquatic hyphomycetes spora in 10 streams of New Brunswick and Nova Scotia.Canadian Journal of Botany 65, 76-79.

Betancourt C, Cruz J, Garcia J. 1987 - Los hifomicetos acuaticos de la Quebrada Dona Juana en el bosque estatal de Toro Negro, Villalba, Puerto Rico. Caribbean Journal of Science 23(2), 278-284.

Castaneda-Ruiz RF, Iturriaga T, Minter DW, Saikawa M, Vidal G, Velazquez-Noa S. 2003 Microfungi from Venezuela, a new species of Brachydesmiella, a new combination, and new records. Mycotaxon 85, 211-229.

Chan SY, Goh TK, Hyde KD. 2000 - Ingoldian fungi in Hong Kong. In:Aquatic Mycology across the Millennium (edsHyde KD, WH Ho, Pointing SB). Fungal Diversity, Hong Kong89-107.

Chauvet E. 1991 - Hyphomycete distribution in South-Western France. Journal of Biogeography 18(6), 699-706.

Chen JS, Feng MG, Fomelack TS. 2000 - Aquatic and aero-aquatic hyphomycetes occurred in central Cameroon, Western Africa. Pakistan Journal of Biological Sciences 3(11), 1847 1848.

Crane JL. 1968 - Hyphomycetes of the northern Appalachian highland including New England, and three coastal plain states. American Journal of Botany 55(8), 996-1002.

Cressa C, Smits G. 2007 - Aquatic hyphomycetes in two blackwater streams of Venezuela. Ecotropicos 20(2), 82-85.

Descals E. 2005 - Techniques for handling Ingoldian Fungi. In: Methods to Study Litter Decomposition (eds Graça MAS, Barlocher F, Gessner MO). Springer, Dordrecht 129-141.

Dixon PA. 1959 - Stream spora in Ghana. Transactions of the British Mycological Society 42(2), 174-176.

Fabre, E. 1998 - Aquatic hyphomycetes in three rivers of southwestern France. II. Spatial and temporal differences between species. Canadian Journal of Botany 76, 107-114.

Fisher PJ, Petrini O. 1989 - Two aquatic hyphomycetes as endophytes in Alnus glutinosa roots. Mycological Research 92(3), 367-368.

Harrington TJ. 1997 - Aquatic hyphomycetes of 21 rivers in southern Ireland. Biology and Environment: Proceedings of the Royal Irish Academy 97(2), 139 -148.

Ingold CT, Cox VJ. 1957 - On Tripospermum and Campylospora. Transactions of the British Mycological Society 40(3), 317-321. 
Ingold CT, Ellis EA. 1952 - On some hyphomycete spores, including those of Tetracladium maxilliformis from Wheatfen. Transactions of the British Mycological Society 35, 158-161.

Ingold CT. 1956 - Stream spora in Nigeria. Transactions of the British Mycological Society 39(1), $108-110$.

Ingold CT. 1958 - Aquatic hyphomycetes from Uganda and Rhodesia. Transactions of the British Mycological Society 41,109-114.

Ingold CT. 1959 - Aquatic spora of Omo Forest, Nigeria. Transactions of the British Mycological Society 42(4), 479-485.

Ingold CT. 1974 - Foam spora from Britain.Transactions of the British Mycological Society 63(3), 487-497.

Ingold CT. 1975- Conidia in the foam of two English streams.Transactions of the British Mycological Society 65(3), 522-527.

Kane DF, Tam WY, Gareth Jones EB. 2002 - Fungi colonizing and sporulating on submerged wood in the river Severn, UK. In: Fungal Succession (eds Hyde KD, Jones EBG). Fungal Diversity 10: 45-55.

Kuzuha S. 1973 - Two new species of aquatic hyphomycetes.Journal of Japanese Botany 48, 220224.

Matsushima T. 1989 - Matsushima Mycological Memoirs No 6. Published by the author, Kobe.

Matsushima T. 1993 - Matsushima Mycological Memoirs No 7. Published by the author, Kobe.

MatsushimaT. 1980 - Saprophytic microfungi from Taiwan- Part 1 Hyphomycetes.Published by the author, Kobe.

Nawawi A. 1974 - A new Campylospora. Transactions of the British Mycological Society 63(3), 603-606.

Nemade LC, Patil VR, Patil MS, Chaudhari SA. 2010 - Diversity of fresh water hyphomycetes from Buldhana District (M.S.), India. Journal of Ecobiotechnology 2(6), 17-20.

Nilsson S. 1964 - Freshwater Hyphomycetes. Taxonomy, morphology and ecology. Symbolae Botanicae Upsaliensis, Uppsala.

Ranzoni FV. 1953 - The aquatic hyphomycetes of California. Farlowia 4, 353-398.

Ravijara NS, Sridhar KR, Barlocher F. 1998 - Fungal species richness in Western Ghat streams (southern India): is it related to $\mathrm{pH}$, temperature or altitude? Fungal Diversity 1, 179-191.

Regelsberger B, Messner K. 1987 - Species diversity of aquatic hyphomycetes in four Austrian streams. Mycotaxon 30, 439-454.

Rosa CA, Rosa LH, Medeiros AO, Fonseca FG da. - 2009. Diversidade Microbiana. In: Biota Minas-Diagnóstico do Conhecimento sobre a Biodiversidade no Estado de Minas Gerais. (eds Drummond GM, Martins CS, Greco MB, Vieira F.). Biodiversitas, Belo Horizonte 43 65.

Santos-Flores C, Betancourt-López C. 1994 - Aquatic Hyphomycetes (Deuteromycotina) from Río Loco at Susúa State Forest, Puerto Rico.Caribbean Journal of Science 30(3-4), 262-267.

Santos-Flores CJ, Betancourt-López C. 1997 - Aquatic and water-borne hyphomycetes (Deuteromycotina) in streams of Puerto Rico (including records from other Neotropical locations).College of Arts and Sciences, University of Puerto Rico, Mayaguez.

Sati SC, Arya P. 2009 - Occurrence of water borne conidial fungi in relation to some physicochemical parameters in a fresh water stream. Nature and Science 7(4), 20-28.

Sati SC, Belwal M. 2005 - Aquatic hyphomycetes as endophytes of riparian plant roots. Mycologia 97(1), 45-49.

Schoenlein-Crusius IH, Grandi RAP. 2003. The diversity of aquatic Hyphomycetes in South America. Brazilian Journal of Microbiology 34, 183-103.

Schoenlein-Crusius IH, Milanez AI. 1990 - Hyphomycetes aquáticos no Estado de São Paulo, Brasil. Revista Brasileira de Botânica 13, 61-68.

Schoenlein-Crusius IH. 2002 - Aquatic hyphomycetes from cerrado regions in the state of São Paulo, Brazil. Mycotaxon 82, 457-462. 
Silva RF, Briedis GS. 2009 - Registro de La presencia de hifomicetos acuáticos en rios de la cordillera de la costa, Venezuela. Interciencia 34(8), 589-592.

Silva RF, Briedis GS. 2011 - Hifomicetos acuáticos de la cabecera de rio Guaríco, Estado Carabobo, Venezuela. Interciencia 36(11), 831-834.

Sridhar KR, Kaveriappa KM. 1992 - Aquatic hyphomycetes of Western Ghat streams, India. Sydowia 44, 66-77.

Velloso AL, Sampaio EVSB, Pareyn FGC. 2002 - Ecorregiões propostas para o Bioma Caatinga. Associação Plantas do Nordeste, Instituto de Conservação Ambiental The Nature Conservancy do Brasil, Recife.

Voglmayr H. 1996 - Spores of ingoldian fungi in two Austrian rivulets. Osterreichische Zeitschrift fur Pilzkunde 5, 23-49.

Wood-Eggenschwiler S, Barlocher F. 1983- Aquatic hyphomycetes in sixteen streams in France, Germany and Switzerland. Transactions of the British Mycological Society 81(2), 371-379. 